we must congratulate him on this thesaurus of quasi-biochemical information.

\section{HERITABLE DISORDERS OF CONNECTIVE TISSUE}

By Victor A. McKusick. St. Louis: C. V. Mosby Co., distributed in Great Britain by Henry Kimpton, London. 1960. 90s.

In the whole field of Medicine, it would be hard to pick a related series of problems more difficult than those considered in this book. The physiology of connective tissue is poorly understood; its chemistry is fragmentary; and it is not even certain that connective tissue can justifiably be treated as an entity. The inherited diseases of this enigmatic body component consist of a series of weird conditions, all rare, such as the Marfan and EhlersDanlos syndromes, osteogenesis imperfecta, pseudoxanthoma elasticum and the Hurler syndrome (gargoylism). Although these varied syndromes are readily recognisable in their fully-developed forms, patients frequently display only a few incomplete features. Since there are no specific biochemical tests at present available diagnosis has to be based on appraisal of the clinical phenomena alone, and hence is often uncertain. The medical geneticist has therefore to feel his way through a swamp of uncertainty, with only rare islets of fact on which to place his feet. The skill with which Dr. McKusick performs this difficult feat is really remarkable. Although primarily a clinician, he has marshalled what little is known of the biology and chemistry of connective tissue in a useful preliminary chapter; and in another, has provided a brilliant summary of what medical genetics is about, which should be read by any clinician who is thinking of entering this field. The remainder of the book is devoted to detailed clinical descriptions of the rare syndromes previously enumerated, together with a full account of what is known of their mode of inheritance. Anyone interested in this group of diseases will find this book quite indispensable.

TRANSPLANTATION OF TISSUES, Vol. II

Edited by Lyndon A. Peer. Pp. xiv +690 , illustrated. London: Baillière, Tindall \& Cox. 1959. I60s.

This volume is an up-to-date résumé of most of the relevant work on tissue and organ transplantation. Sections are contributed by specialists in the various fields covered and the aim of the book seems to be to provide the clinician with the salient features of this rapidly expanding field.

The difficulties in accomplishing this task are great since genetic, biochemical and especially immunological considerations, disciplines previously separated from each other and even more remote from clinical practice, are directly pertinent to tissue transplantation problems.

The editor has in the main succeeded in providing a comprehensive and readable book. The obvious defects of multiple authorship result in some repetition, a variable literary standard and occasionally disproportionate emphasis, for example 30 pages are devoted to transplantation of peritoneum, surely a very limited field, in which only autografts are of value and clinicians are already familiar with most of the applications cited.

There is an excellent chapter on the biological aspects of transplantation by Professor Medawar. This is lucid and stimulating and provides a sound scientific basis to the volume.

The references are very full and usually accurate. In some instances unhelpful historical work is mentioned apparently for the sake of completeness. In most chapters the historical backgrounds are very similar, initial early experiments on transplantation were performed with little or no distinction between autografts and homografts and interpretation of graft survival often rested on metaphysical criteria. Later work differentiated the essential technical problems of autografts from the immunological aspects of homografting. The repetition of this evolution in different chapters seems unnecessary.

Considerable space is devoted to anatomical and physiological factors that do not appear to be directly related to tissue transplantation.

A textbook on tissue transplantation is certainly due. This volume, in spite of some excessive and irrelevent content, does provide a pertinent discussion of the problems involved in experimental work and clinical applications of both autografts and homografts.

There are chapters on transplantation of the following tissues, skin, cornea, fat, nerves, teeth, blood vessels, endocrine glands, organs, peritoneum and cancer cells.

\section{THE CARE OF MINOR HAND INJURIES}

By A. E. Flatt. Pp. 266. St. Louis: The C.U. Mosby Co., distributed in Great Britain by Henry Kimpton, London. 1959. 71s. 6d.

The author has rightly criticised his own choice of title, inferring that there is no such thing as a minor injury where the hand is concerned.

The scope of this book has been restricted largely to the types of injury which can be treated in the out-patient department. As such it will be of great value to the Casualty Officer, and the Practitioner who may be obliged to treat most of his hand injuries without the resources of a large hospital at his doorstep.

The first section deals with the general principles of care and can only be criticised by someone having a rooted objection to the use of local anaesthetics.

The second section deals with the care of specific injuries and by virtue of the fact that each chapter is comprehensive, contains a lot of repetition. This 
arrangement, however, makes for rapidity and ease of reference.

The text is dogmatic. Too dogmatic where the treatment of pulp loss is concerned. Loss of the special sense organs in the pulp of the finger can never be replaced by a thenar flap. In the rare case where closure by split skin graft or shortening of the distal phalanx do not apply, an island pedicle graft is the only means of restoring anything like normal sensation.

The statement that occupational therapy has very little place to offer in the treatment of minor hand injuries fails to acknowledge the help that a wellequipped centre can provide in re-acclimatising an injured hand to the feel of machinery.

To lay too much stress on points such as these would be unnecessarily carping, since through its didactic approach the book derives much of its value. Equipped with this the Casualty Surgeon cannot go far wrong, and it should help materially to reduce the growing wastage of man-hours resulting from injuries of the hand.

\section{ANTIBIOTICS IN MEDICINE}

British Medical Bulletin, 1960, Vol. I6, No. I, 88 pages. 20 s.

During the past i 5 years the number of clinically useful antibiotics has increased from one, penicillin, to about 15. The newer antibiotics have been discovered almost exclusively by vast efforts and expenditure by the pharmaceutical industry. Their chief aims have been to find substances which will control infections hitherto unresponsive to chemotherapy, to find drugs which will deal with organisms that have become resistant to available antibiotics, and to find less toxic compounds.

The present number of the British Medical Bulletin is a survey of all the important aspects of the antibiotic field and, to indicate its scope, I can do no better than give the titles and authors of all the contributors to this excellent volume.

There is an introduction by the scientific editor, Professor L. P. Garrod. Then follow sections on: Chemistry and classification of antibiotics, by E. P. Abraham and G. G. F. Newton. The nature of the selective toxicity of antibiotics, by $\mathrm{E}$. F. Gale. Drug resistance and mechanisms for its development, by Mr. R. Pollock. The principles of therapeutic use of antibiotics, by L. P. 'Garrod and E. F. Scowen. The laboratory control of antiobiotic therapy, by J. C. Gould. The pharmacology of antibiotics, by J. M. Robson and G. A. H. Buttle. The rationale and management of combined therapy, by B. W. Lacey. Preventive use of antibiotics in medicine, by E. G. L. Bywaters. Preventive use of antibiotics in surgery, by Gerard W. Taylor. The chemotherapy of tuberculosis, with special reference to patients whose bacilli are resistant to the standard drugs, by John Crofton. The treatment of bacterial endocarditis, by A. Eric Dormer. The dangers of antibiotic treatment, by
D. M. Dunlop and J. McC. Murdoch. Clinical problems of drug-resistant pathogens, by E. J. L. Lowbury. Laboratory uses of antibiotics, by Robert Cruickshank. The search for new antibiotics, by A. H. Campbell.

This number of the British Medical Bulletin is an outstanding contribution to the literature and views on antibiotics and should be read by everyone who wants to bring himself up to date in this most important branch of medicine.

\section{EARLY DIAGNOSIS}

By various authors. Edited by Henry Miller, M.D., F.R.C.P. Pp. 400. Edinburgh and London: E. \& S. Livingstone Ltd. $25 \mathrm{~s}$.

This book contains 25 chapters, each written by a different author, and a very good index. It was an excellent idea to invite authors having such widely varying interests to contribute: among them are to be noted two General Practitioners and seven Professors, surely an unusually broad spectrum of authority to be found within the covers of a single volume! Lord Cohen contributes a characteristically vigorous and practical introductory chapter entitled 'On Early Diagnosis' which sets the standard for the book as a whole. In his Preface, Dr. Miller says that it has been written for the general practitioner, who bears special responsibility for the early recognition of important disease. In fact, both junior house officers and consultants will read the book with profit. Such a masterly exposition of sheer clinical sense, for instance, as Professor Dunlop's four pages on the diagnosis of Hyperthyroidism, is hard to equal anywhere.

The essential facts about the early manifestations of a very large number of clinical conditions are given in this book, put in a new and stimulating form, so that even those well acquainted with them will find an interest in this variation of the usual text book presentation. The book may therefore be strongly recommended not only to those engaged in the day-to-day practice of their profession, but to anyone seeking to revise his knowledge or to sharpen his clinical wits - to all clinicians, in fact.

\section{THE FUNCTIONS OF THE ENDOCRINE GLANDS}

By P. F. Hall, M.D., M.R.A.C.P. Pp. 290, figs. 77. Sydney: Horwitz Publications Inc.; London: Pitman Medical Publishing Co. Ltd.; Philadelphia: W. B. Saunders Company.

There has long been a need for a short book of this type, and the author is to be congratulated on the excellent way in which he has dealt with it. This book is not so specialized and abstruse that it cannot be read by the practising clinician with no great knowledge of physiology and endocrinology; it is not packed with so many formulae, references 